\title{
Comprehensive study on smart cooling techniques used for batteries
}

\author{
Amey Ekbote, ${ }^{1, *}$, Mathew Karvinkoppa ${ }^{1}$, Virendra Bhojwani ${ }^{l,}$ and Naveen Patil ${ }^{2}$ \\ ${ }^{1}$ MIT School of Engineering, Rajbaug Loni, Pune-412201, India \\ ${ }^{2}$ Vellore Institute of Technology, Vellore, Tamil Nadu, India
}

\begin{abstract}
Electric vehicles are important in today's world to reduce pollution. The demand for electric vehicles is increasing day by day. The major component is the battery for an electric vehicle which gives the power to drive motor and drives the vehicle. Continuous operation of the vehicle causes the battery to heat and while heating there are some flammable gases released which may cause a fire. The heating of batteries reduces the performance of the vehicle and reduces the efficiency, therefore there is a need for cooling techniques to keep the temperature of batteries below the critical temperature for safe operating conditions. The present study emphasizes various cooling techniques used for the battery thermal management system. Cooling improves the performance of the battery and reduces the temperature of the battery. It helps in maintaining the temperature of the battery at the desired level. Before cooling the battery, it is necessary to study the thermal behavior of the battery. Various aspects of the thermal behavior are also reported in the paper and the problems associated with the time required for charging the batteries are also discussed.
\end{abstract}

\section{Introduction}

Conventional vehicles cause pollution leading to global warming which is affecting our daily life [1]. The only solution to reduce pollution due to transportation is by using eco-friendly electric vehicles. Electric vehicles do not harm the environment which does not operate on conventional fuels.

Electric vehicles have a battery that stores the energy and drives the motor shaft of the vehicle. In most cases, lead-acid or lithium-ion batteries are used. Lithium-ion batteries take less time than lead-acid batteries for charging. There is an increase in internal heat generation occurs due to continuous usage of battery causing the rise in the temperature of the system and the performance of the battery reduces. The continuous usage of battery may lead to failure and a small change in the wiring diagram may lead to a short circuit too. The batteries generating heat consume more power and it reduces the economy of the vehicle. The parameters that affect the performance of battery due to a rise in temperature are given below:

- Electrochemical reaction in the battery

- Vehicle mileage

- Charging time

- Reliability

- Life of battery

*Corresponding author: ameyekbote9@gmail.com
To cool down the temperature of batteries and keep the temperature below the desirable for the effective working of them, various cooling systems are studied in this topic. The cooling system plays a vital role in removing heat from batteries. Cooling systems reduce the temperature of the battery. The various cooling techniques are developed to reduce the temperature of the battery. One of the advantages of using a cooling system is the performance of the vehicle gets improved and increases the life of the battery. Air cooling, liquid cooling, and the use of phase change material (PCM) are some of the cooling techniques used in batteries. According to the concept of heat transfer heat travels from the hightemperature areas to the low-temperature area. In the current study, the battery thermal management system and preheating of battery is also discussed. Battery thermal management plays a chief role in heat analysis. Battery thermal management aims to distribute the temperature uniformly. The goals of battery thermal management system are (a) to maintain temperature of the battery (b) uniform temperature distribution (c) to maximize the heat dissipation

\section{Battery Thermal Management System}

Battery thermal management system (BTMS) [24] is used for maintaining temperature conditions in electric vehicles. A thermal imbalance affects the performance of 
the battery. Heating causes a reduction in the life span of cells. It is observed that hot cells degrade quickly compared to cold cells. Arrhenius law states that the chemical reaction in battery increases exponentially with the battery cell temperature. The lithium-ion battery system should have the maximum cell temperature below $40{ }^{\circ} \mathrm{C}$ and the cell temperature difference below $5{ }^{\circ} \mathrm{C}$. Due to this life span of the battery is maintained. The aim of thermal management is maintaining uniform temperature [24].

A systematic approach has been shown while studying thermal management. Following are steps for designing and evaluating a BTMS are given below:

1. Specifications for modules and packs should be identified under different climates like geometric entities, dimensions, number of modules, and positions, based on the vehicle integrators requirements should be identified.

2. Calculate overall heat generation and overall heat capacity from the module at different discharge cycles and temperature.

3. Determine the steady-state temperature of modules using energy balance principles under operating conditions. By using these fans or pumps power requirements can be quoted with a selection of coolant fluids.

4. Carry out Finite Element Analysis to understand the thermal behavior of modules. Using Computational Fluid dynamics heat transfer rate can be obtained and systems power requirements can be evaluated. The impact can be studied on modules.

5. Design a battery module with fans and cooling materials and carry out the detailed experiment. The analysis must include cost estimation, FEA validation, maintenance, ease of operation, and comparison with an alternative system.

6. Build a system of the module and test it under different climatic conditions. Observe performance at various flow rates.

7. Carry out the optimization of the system. Several factors are taken into consideration such as battery performance and life, impact on vehicle performance, cost, and ease of maintenance while doing optimization.

\section{Cooling methods}

Cooling takes place under temperature difference. Cooling can be done using air or liquid as coolant media. Heat transfer plays a key role in the cooling of the battery. Heat transfer includes conduction, convection, and radiation. Conduction takes place between two solid particles one having more energy and the other one having less energy. The heat transfer rate in conduction is more compared to convection and radiation. heat conduction occurs due to two effects: the vibrational motions of the molecules positioned at relatively fixed positions periodically induce the lattice vibrational waves called a lattice, and the energy gets traveled via the free flow of electrons in the solid. Convection is a mode of heat transfer in which heat exchange takes place between solids and liquids or gases. Convection is classified as natural convection and forced convection. In natural convection, the heating body is exposed to natural phenomena while in forced convection external device is used to remove heat. Radiation takes place by electromagnetic waves i.e change in molecular configuration or atomic structure. In radiation, there is no intervening medium required. These modes of heat transfer play a vital role in the removal of heat while cooling. Cooling can be classified as active cooling or passive cooling. The active cooling method uses a fan to remove heat while in passive cooling natural cooling takes place. Cooling methods are described below

\subsection{Air cooling}

The heat transfer medium plays a prime role in removing heat. For the removal of heat, air can be used as a medium. Air cooling is a method for dissipating heat [2]. It is done by increasing the surface area or increasing the airflow over the object to be cooled, or both. Mathew and Hotta [25-26] carried out numerical studies to cool integrated circuits which acts as a hot spot. They used natural, forced, and mixed convection methods for cooling these hotspots generated in IC chips. They observed the effect of cooling using a fluent solver. These cooling methods were found to be effective for cooling circuits. The methodology adopted by them is also feasible for battery modules.

\subsection{Liquid Cooling}

In some cases, air cooling is not preferable as it cannot access some parts present inside vehicles [28]. Liquid cooling is preferred when the temperature of the ambient condition is more than $35^{\circ} \mathrm{C}$, in an enclosed system where less volume of air enters inside the parts, and when there is a higher heat flux removal rate. Liquid cooling consists of fluid which removes heat from surrounding. In this type, the flow rate of liquid can be increased and recirculate. Designing of a liquid system is simple and liquids have high thermal conductivity (HTC) and high heat transfer coefficient (HHTC) [28]. Sometimes liquid cooling systems have problems like leakage, corrosion, extra weight, and condensation, and even cavitation that may take place in tubes. There are some factors which are taken into the selection of fluid mentioned below

- High specific heat

- Low viscosity

- High latent heat of vaporization

- High boiling point

- Low freezing point

- Non-corrosive and non-inflammable

Liquid cooling systems are of two types viz. direct cooling and indirect cooling systems. Indirect cooling systems, the cooling system has contact with components. While in the case of the indirect cooling system they don't have contact with components. Liquid cooling systems have closed-loop and open-loop systems, depending on whether the liquid is discharged or sent again into the system after it is heated. In open-loop systems, fluid is passed through the cooling system and discharged into a drain when it is heated. The hot fluid in closed-loop 
systems is cooled using a heat exchanger and recirculated to the system again. Patil and Hotta [27] used different fluids for studying the cooling effect on integrated circuits. They used fluids like FC-72, water and they carried out analysis using software Ansys Icepak. Patil and Hotta [28] used water, FC-72, dielectric fluids, nanofluids for studying the cooling effect on electronic modules. They studied the characteristics of these working fluids and these can remove heat at high temperatures.

\subsection{Phase Change Materials (PCMs)}

Phase changing materials are the ideal material for thermal applications. These materials store and release energy while melting and freezing processes [9]. When freezing occurs a large amount of energy is released by these materials. These materials absorb energy during the melting process. Generally, these materials are used in passive thermal management and developed as an alternative to active cooling. The advantage is that they absorb a large amount of heat. Phase change materials are more efficient in the forced convection method. PCMs play a key role in the battery thermal management system and its shape is simple, light, and requires less space. Mathew and Hotta [31-32] used phase changing material for studying temperature characteristics. They used different PCMs to cool down the temperature of IC chips mounted on the SMPS board. PCMs showed effective cooling and it can be used for cooling battery modules. The studies conducted by authors [26-32] mainly focuses on identifying the hot spot at the board level. These hots spots are further cooled down using various cooling techniques as discussed. Thes cooling techniques are also feasible at the battery module level and the temperature of the modules can be reduced.

\section{Background of cooling studies}

Various researchers have carried studies on battery cooling techniques. The main objective is to increase the performance of the battery. Cost optimization and weight reduction is also a major factor. Sometimes system weight is also taken into consideration while designing a system. A background study carried out by researchers is given in Table 1.

Table 1. Summary of the literature pertains to cooling of Batteries

\begin{tabular}{|c|c|c|}
\hline Author & Coolant & Parameters \\
\hline $\begin{array}{l}\text { Ahmad A. Pesaran and } \\
\text { Matthew Keyser [1] }\end{array}$ & - & $\begin{array}{l}\text { - Various tests were performed to carry out the thermal analysis of the } \\
\text { battery. } \\
\text { Battery modules used for testing were valve-regulated lead-acid, } \\
\text { lithium-ion, and nickel-zinc and heat generation capacity and thermal } \\
\text { imaging carried out. }\end{array}$ \\
\hline Ahmad A. Pesaran [2] & Air & $\begin{array}{l}\text { - } \quad \text { Developed a model for thermal analysis } \\
\text { - } \quad \text { Lump capacitance model for temperature analysis } \\
\text { - } \quad \text { Finite elements to observe effects on the model }\end{array}$ \\
\hline Ahmad A. Pesaran [3] & Air, liquid & $\begin{array}{l}\text { - } 60 \mathrm{~Hz} \text { AC power supply was given to a } 12 \text { volt, } 13 \text { Ah battery for heating } \\
\text { - } \quad \text { Experiments were carried at }-40^{\circ} \mathrm{C} \text { where warming of battery took } \\
\text { place } \\
\text { - By conducting experiments transient behavior and preheating of the } \\
\text { battery was studied }\end{array}$ \\
\hline $\begin{array}{l}\text { Anthony Jarrett, Yong } \\
\text { Kim* [4] }\end{array}$ & Air & $\begin{array}{l}\text { - } 1 \mathrm{~mm} \times 160 \mathrm{~mm} \times 200 \mathrm{~mm} \text { dimensions of cold plate used for analysis } \\
\text { - } \quad \text { CFD analysis was carried out } \\
\text { - Optimization was studied using parameters coolant pressure drop, } \\
\text { temperature uniformity, and average temperature }\end{array}$ \\
\hline $\begin{array}{l}\text { Rajib Mahamud, } \\
\text { Chanwoo Park [5] }\end{array}$ & Air & $\begin{array}{l}\text { - } \quad \text { Carried out CFD and developed the lumped capacitance model } \\
\text { - } \quad \text { Carried out a study on reciprocating air flow method }\end{array}$ \\
\hline $\begin{array}{l}\text { Rajib Mahamud and } \\
\text { Chanwoo Park [6] }\end{array}$ & Air & $\begin{array}{l}\text { - Lump capacitance method is studied } \\
\text { - An analysis is done by considering biot number }<0.1 \\
\text { - They used lithium-ion cell which is constructed using multiple layers } \\
\text { and Material of cell is non-homogenous and non-isotropic } \\
\text { - The lumped-capacitance thermal model was used to calculate the core, } \\
\text { average and surface temperatures of the cell under battery duty cycles } \\
\text { - They kept convective heat transfer coefficients } 151.9,1519,7600 \text {, and } \\
15200 \mathrm{~W} / \mathrm{m}^{2}-\mathrm{K} \text { that were corresponding to the Biot numbers of } 0.1,1 \text {, } \\
5 \text {, and } 10, \text { respectively. } \\
\text { - Accurate results were obtained using CFD modeling }\end{array}$ \\
\hline
\end{tabular}




\begin{tabular}{|c|c|c|}
\hline $\begin{array}{l}\text { Thanh-Ha Tran, et al } \\
\text { [7] }\end{array}$ & Air, liquid & $\begin{array}{l}\text { - They used } 14 \text { cylinder cells battery modules having } 6.5 \text { Ah of capacity, } \\
\text { and dimensions } 38 \mathrm{~mm} \text { in diameter and } 142 \mathrm{~mm} \text { in height } \\
\text { - Heat pipe cooling system was used to cool the battery } \\
\text { - They used } 4 \text { modules, each module consists of } 7 \text { tubes with } 50 \text { helical } \\
\text { grooves } \\
\text { - Using heat pipe power consumption and noise level can be reduced }\end{array}$ \\
\hline M.C. Browne et al [8] & $\begin{array}{l}\text { Phase } \\
\text { changing } \\
\text { material } \\
(\mathrm{PCM})\end{array}$ & $\begin{array}{l}\text { - They studied the effects of temperature on photovoltaic cell } \\
\text { - They reviewed about phase change materials and studied their } \\
\text { parameters } \\
\text { - They also studied the effects of phase change materials }\end{array}$ \\
\hline Ziye Ling, et al [9] & Air & $\begin{array}{l}\text { - The battery was tested under two conditions viz .completely passive } \\
\text { system and hybrid passive system } \\
\text { In a completely passive system battery was surrounded by RT44HC } \\
\text { composite while in hybrid system battery with phase changing material } \\
\text { was exposed to forced air convection. } \\
\text { - They carried out a comparison between the performance of passive and } \\
\text { active thermal management systems } \\
\text { - Using PCM with an active cooling system increases the cooling } \\
\text { efficiency }\end{array}$ \\
\hline $\begin{array}{l}\text { Shahabeddin K. } \\
\text { Mohammadian et al } \\
{[10]}\end{array}$ & $\begin{array}{l}\text { Liquid } \\
\text { electrolyte } \\
\text { and water }\end{array}$ & $\begin{array}{l}\text { - The prismatic structured battery was used to observe thermal } \\
\text { management } \\
\text { - Heat generation causes failure and heat dissipation in battery } \\
\text { - Internal and external cooling methods were used for cooling battery } \\
\text { - Internal cooling is differentiated with the external one } \\
\text { - They observed temperature distribution using numerical and graphical } \\
\text { analysis } \\
\text { - The internal cooling method reduces the temperature inside the battery } \\
\text { and also improves temperature distribution. }\end{array}$ \\
\hline $\begin{array}{l}\text { Bahman Shabani and } \\
\text { Manu Biju [11] }\end{array}$ & Air & $\begin{array}{l}\text { - Transient conduction approach was used for uniform temperature } \\
\text { distribution } \\
\text { - } \quad \text { Various governing equations were used to carry heat analysis } \\
\text { - } \quad \text { Lumpe finite element method was used to study behavior. } \\
\text { Thermal Models and Equivalent Circuit Thermal Models methods are } \\
\text { used and deep analysis is carried out. }\end{array}$ \\
\hline Dafen Chena et al [12] & Liquid & $\begin{array}{l}\text { - Air cooling, liquid cooling( direct and indirect), and fin cooling } \\
\text { techniques were used to see cooling effects. } \\
\text { - A prismatic cell was made using software ANSYS/Fluent which is } \\
\text { based on electrochemical reaction theory and its performance was } \\
\text { studied } \\
\text { - } \quad \text { Dielectric mineral oil is used in direct liquid cooling. } \\
\text { - } 169 \mathrm{~mm} \times 197 \mathrm{~mm} \times 1 \mathrm{~mm} \text { was the dimensions of the fin } \\
\text { - The average temperature increase was observed at the end of discharge } \\
\text { reach a minimum of } 4^{\circ} \mathrm{C} \text { so that all cooling methods were observed } \\
\text { - Fin cooling adds weight while air cooling consumes more power }\end{array}$ \\
\hline Lan et al [13] & Air & $\begin{array}{l}\text { - Mini channels were tested at different flow rates and directions and } \\
\text { results were calculated } \\
\text { - } 173 \times 168 \times 39 \mathrm{~mm} \text { were dimensions of battery module while the } \\
\text { dimension of channel } 3 \times 3 \mathrm{~mm} \\
\text { - It was tested at } 15^{\circ} \mathrm{C} \text { and } 35^{\circ} \mathrm{C} \text { and analyzed } \\
\text { - This system was found superior for battery thermal management } \\
\text { system }\end{array}$ \\
\hline S.Panchal*, et al [14] & Water & $\begin{array}{l}\text { - An aluminum-laminated battery was used which contains LiFePO4 } \\
\text { cathode material } \\
\text { - The rating of the battery was } 20 \mathrm{Ah} \text {. }\end{array}$ \\
\hline
\end{tabular}




\begin{tabular}{|c|c|c|}
\hline & & $\begin{array}{l}\text { - Thermocouples and heat flux sensors were used to detect temperature } \\
\text { variation. } \\
\text { - The dual cold plate approach was used and studied cooling at different } \\
\text { temperatures from } 5^{\circ} \text { to } 35^{\circ} \mathrm{C} \text {. } \\
\text { - As current discharge increases heat generation increases }\end{array}$ \\
\hline L. H. Saw, et al [15] & Air & $\begin{array}{l}\text { - The battery pack was used consisting of } 24 \text { pieces of } 38,120 \text { cells } \\
\text { - The heat generated was measured using the calorimeter } \\
\text { - Various mass flow rates were applied to analyze air cooling } \\
\text { - They found a correlation between Nusselt number and Reynolds } \\
\text { number }\end{array}$ \\
\hline Chen et al [16] & Air & $\begin{array}{l}\text { - The battery pack was used consisting of } 24 \text { pieces of } 38,120 \text { cells } \\
\text { - The heat generated was measured using the calorimeter } \\
\text { - Various mass flow rates were applied to analyze air cooling } \\
\text { - They found a correlation between Nusselt number and Reynolds } \\
\text { number }\end{array}$ \\
\hline Wang et al [17] & Air & $\begin{array}{l}\text { - Thermal stability of components of a lithium-ion battery is being } \\
\text { - } \quad \text { Heat generation and thermal runaway has been studied } \\
\text { - Working and arrangement of lithium-ion battery has been explained } \\
\text { - They investigated the thermal effects of battery on various passenger } \\
\text { - } \quad \text { Thehicles } \\
\text { - They investigated the performance of battery at sub-zero temperature }\end{array}$ \\
\hline \multirow[b]{2}{*}{ S. Panchal et al [18-19] } & Water + Air & $\begin{array}{l}\text { - Testing was done at temperatures between } 5^{\circ} \mathrm{C} \text { and } 25^{\circ} \mathrm{C} \text { using air } \\
\text { cooling and water cooling method. } \\
\text { - Using lab view software parameters were recorded like charge and } \\
\text { discharge current, charge and discharge voltage, and sampling. } \\
\text { - By increasing the temperature discharge rate increases. } \\
\text { - } \quad \text { The cooling patterns obtained from the numerical results were stable }\end{array}$ \\
\hline & Water & $\begin{array}{l}\text { - Mini -channel cold plates are used for cooling of battery modules } \\
\text { - Water is used as fluid to act as coolant and water was set at a } \\
\text { temperature } 5^{\circ} \mathrm{C}, 15^{\circ} \mathrm{C} \text { and } 25^{\circ} \mathrm{C} \\
\text { - Computational Fluid Dynamics is studied using Reynolds Averaged } \\
\text { Navier Strokes equation. } \\
\text { - Temperature distribution and velocities were compared in } \\
\text { minichannels }\end{array}$ \\
\hline Jian Xu et al [20] & $\begin{array}{l}\text { Ethylene } \\
\text { glycol and } \\
\text { water }\end{array}$ & $\begin{array}{l}\text { - } \quad \text { Mini-channel cooling system was designed for battery cooling } \\
\text { - } \quad \text { Nail penetration technique was used to avoid circuit failure } \\
\text { - The dimensions of each cell were } 180 \mathrm{~mm} \text { X } 130 \mathrm{~mm} \text { X } 50 \mathrm{~mm} \text { and the } \\
\text { rating was } 55 \mathrm{Ah} \text {. } \\
\text { - They conducted an experiment and model was validated and carried out } \\
\text { numerical analysis } \\
\text { - } \quad \text { Fluids ethylene glycol was compared with water }\end{array}$ \\
\hline $\begin{array}{l}\text { Abdul Haq Mohammed } \\
\text { [21] }\end{array}$ & Water & $\begin{array}{l}\text { - Two types of cold plates were used one with s-type and other with } \\
\text { pin-type design } \\
\text { - } \\
\text { - } \quad \text { The flow rate was kept } 0.2 \mathrm{~L} / \mathrm{min} \text { and } 0.3 \mathrm{~L} / \mathrm{min} \text { in s-type and pin type } \\
4.1^{\circ} \mathrm{C} \text { and } 4.2^{\circ} \mathrm{C} \text { temperature drop was observed } \\
\text { - High-pressure drop values occurred in S-type design compared to the } \\
\text { pin type design. }\end{array}$ \\
\hline Ben Ye, et al [22] & Air & $\begin{array}{l}\text { - } 131 \mathrm{~mm} \times 65 \mathrm{~mm} \text { X16mm was a dimension of the battery. } \\
\text { - The comparison was done between experimental analysis and CFD } \\
\text { temperatures } \\
\text { - They carried out cost optimization }\end{array}$ \\
\hline Ahmed pearsan [23] & Air & $\begin{array}{l}\text { - } \quad \text { Carried out finite element analysis } \\
\text { - } \quad \text { Then used Infrared photography to obtain thermal images } \\
\text { - } \quad \text { liquid crystal thermography to obtain thermal images } \\
\text { - } \quad \text { selected air at } 25^{\circ} \mathrm{C} \text { for cooling the module } \\
\text { - }\end{array}$ \\
\hline
\end{tabular}




\begin{tabular}{|c|c|c|}
\hline A.A. Pesaran et al [24] & Air & $\begin{array}{l}\text { - Steps for studying battery thermal management system are given } \\
\text { - For the ideal design of the battery, the BTMS approach is useful } \\
\text { - Various methods are discussed to observe uneven temperature } \\
\text { distribution } \\
\text { - }\end{array}$ \\
\hline
\end{tabular}

\section{Emerging Smart technologies in cooling}

New cooling technologies impress the market today. The major factor is cost optimization and improving the performance of the system. These techniques play a vital role in the cooling of the battery. After carrying out extensive study researchers have developed smart cooling technologies. By using these concepts temperature of the battery can be controlled. Some techniques are shown below:

\subsection{Cabin Air Cooling}

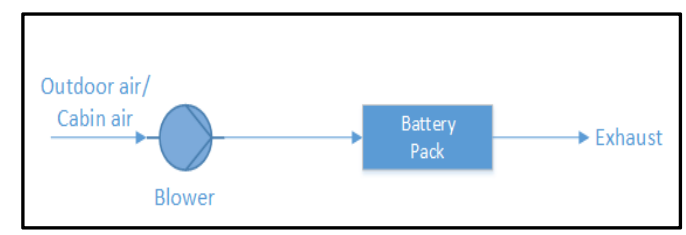

Fig 1. Air cooling [33]

This system is used in the Toyota Prius [33]. Preconditioned air from air conditioning is used for battery cooling. Airflow takes place over a surface and channels through the battery.

\subsection{Independent Air Cooling}

This system is similar to cabin air cooling. This system consists of an evaporator that removes heat from the battery. Refrigerant gets evaporated at low temperature and absorbs heat. Thus battery gets cooled below cabin temperature.

\subsection{Direct refrigerant cooling}

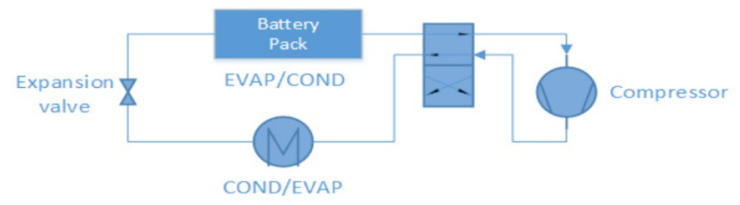

Fig 2. Direct Refrigerant cooling [33]

Direct refrigerant connects an evaporator plate in parallel with the current evaporator of vehicle air condition. Evaporator plates have direct contact with the battery plate.

\subsection{Thermoelectric Cooling}

In the thermoelectric cooling conversion of electric voltage takes into temperature difference using thermoelectric modules. Heat transfer takes place directly by consuming electricity. It can be used for heating applications just by reversing poles.

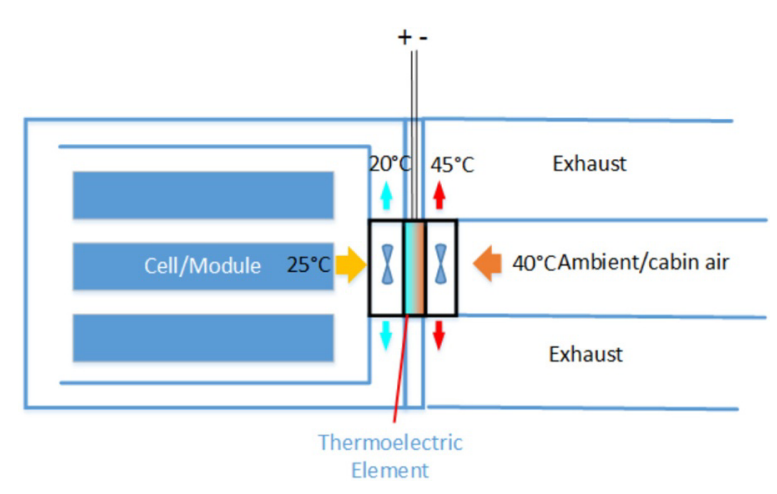

Fig 3. thermoelectric cooling [33]

\subsection{Heat Pipe Cooling}

The heat pipe is another solution for cooling batteries. The heat pipe is an envelope of pipes having a capillary powder structure with sintered copper powder. It is used as an evaporator which absorbs heat while operation and dissipates heat in the condenser and becomes liquid again.

\subsection{Combinational liquid cooling system}

This system has four modes: bypass with heater modes, passive cooling, and active cooling This system can be used as passive cooling as well as active cooling. Passive cooling is most preferred as it has simple architecture and has low power consumption

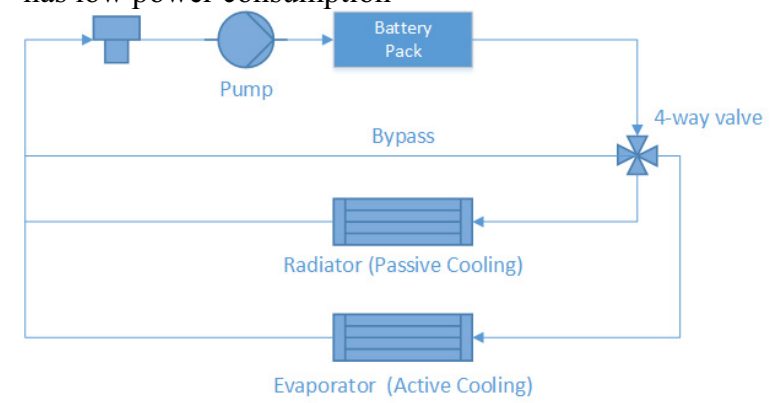

Fig 5. combinational System [33] 


\section{Preheating Techniques}

All batteries create problems during cold climatic conditions[3]. Electrochemical processes become slow and overall internal resistance increases in the winter season. Due to slow initialization, starting of the vehicle becomes hard. Some steps are given below The battery core could be heated internally by applying electricity (electrochemical components)[24].

- External heating can be done for a module using an electric heater

- Each cell in a module can be heated externally using an electric heater.

- Internal heating can be done for each cell using a hot fluid.

- Internal Hot fluid heating method can be used for preheating of each module.

\section{Conclusion}

Electric vehicles are major key players in the market. Batteries are key components for power generation. Cooling systems are necessary to improve performance. Cooling systems reduce the heat generation of the system. They always try to cool the system without affecting the internal system thus increasing the mileage of vehicles. Various types of cooling systems are discussed. Every cooling system has its uniqueness. The major problem is the cost of the system gets increased. Hence researchers have also studied cost optimization. Due to this cost of the system gets reduced. These new emerging technologies play a vital role in the cooling system. The battery reactions get easily initiated. Battery Thermal Management is useful for studying temperature effects. The systematic approach for temperature distribution is also discussed. The currents study will help the researcher to choose the appropriate battery cooling technique considering all the crucial factors.

\section{References}

[1] A. A. Pesaran and M. Keyser, "Thermal characteristics of selected EV and HEV batteries," in Sixteenth Annual Battery Conference on Applications and Advances. Proceedings of the Conference (Cat. No.01TH8533), Long Beach, CA, USA, 2001, pp. 219-225.

[2] A. A. Pesaran, "Battery thermal models for hybrid vehicle simulations," Journal of Power Sources, vol. 110, no. 2, pp. 377-382, Aug. 2002.

[3] A. Pesaran, A. Vlahinos, and T. Stuart, "Cooling and Preheating of Batteries in Hybrid Electric Vehicles," p. 7, 2003.

[4] A. Jarrett and I. Y. Kim, "Design optimization of electric vehicle battery cooling plates for thermal performance," Journal of Power Sources, vol. 196, no. 23, pp. 10359-10368, Dec. 2011.
[5] R. Mahamud and C. Park, "Reciprocating airflow for Li-ion battery thermal management to improve temperature uniformity," Journal of Power Sources, vol. 196, no. 13, pp. 5685-5696, Jul. 2011.

[6] R. Mahamud and C. Park, "Spatial-Resolution, Lumped-Capacitance Thermal Model for Battery Power Cycle Analysis," presented at the SAE 2011 World Congress \& Exhibition, 2011, pp. 2011-01-1362.

[7] T.-H. Tran, S. Harmand, and B. Sahut, "Experimental investigation on heat pipe cooling for Hybrid Electric Vehicle and Electric Vehicle lithium-ion battery," Journal of Power Sources, vol. 265, pp. 262272, Nov. 2014.

[8] M. C. Browne, B. Norton, and S. J. McCormack, "Phase change materials for photovoltaic thermal management," Renewable and Sustainable Energy Reviews, vol. 47, pp. 762-782, Jul. 2015.

[9] Z. Ling, F. Wang, X. Fang, X. Gao, and Z. Zhang, "A hybrid thermal management system for lithium ion batteries combining phase change materials with forcedair cooling," Applied Energy, vol. 148, pp. 403-409, Jun. 2015.

[10]S. K. Mohammadian, Y.-L. He, and Y. Zhang, "Internal cooling of a lithium-ion battery using an electrolyte as coolant through microchannels embedded inside the electrodes," Journal of Power Sources, vol. 293, pp. 458-466, Oct. 2015.

[11]B. Shabani and M. Biju, "Theoretical Modelling Methods for Thermal Management of Batteries," Energies, vol. 8, no. 9, pp. 10153-10177, Sep. 2015.

[12] D. Chen, J. Jiang, G.-H. Kim, C. Yang, and A. Pesaran, "Comparison of different cooling methods for lithium-ion battery cells," Applied Thermal Engineering, vol. 94, pp. 846-854, Feb. 2016.

[13] C. Lan, J. Xu, Y. Qiao, and Y. Ma, “Thermal management for high power lithium-ion battery by minichannel aluminum tubes," Applied Thermal Engineering, vol. 101, pp. 284-292, May 2016.

[14] S. Panchal, I. Dincer, M. Agelin-Chaab, R. Fraser, and M. Fowler, "Experimental and theoretical investigations of heat generation rates for a water cooled LiFePO 4 battery," International Journal of Heat and Mass Transfer, vol. 101, pp. 1093-1102, Oct. 2016.

[15] L. H. Saw, Y. Ye, A. A. O. Tay, W. T. Chong, S. H. Kuan, and M. C. Yew, "Computational fluid dynamic and thermal analysis of Lithium-ion battery pack with air cooling," Applied Energy, vol. 177, pp. 783-792, Sep. 2016.

[16] K.-H. Chen, T. Han, B. Khalighi, and P. Klaus, "Air Cooling Concepts for Li-Ion Battery Pack in Cell Level," in Volume 1: Aerospace Heat Transfer; Computational 
Heat Transfer; Education; Environmental Heat Transfer; Fire and Combustion Systems; Gas Turbine Heat Transfer; Heat Transfer in Electronic Equipment; Heat Transfer in Energy Systems, Bellevue, Washington, USA, Jul. 2017, p. V001T09A001, doi: 10.1115/HT2017-4701.

[17] Q. Wang, B. Jiang, B. Li, and Y. Yan, “A critical review of thermal management models and solutions of lithium-ion batteries for the development of pure electric vehicles," Renewable and Sustainable Energy Reviews, vol. 64, pp. 106-128, Oct. 2016.

[18] S. Panchal, R. Khasow, I. Dincer, M. Agelin-Chaab, R. Fraser, and M. Fowler, "Numerical modeling and experimental investigation of a prismatic battery subjected to water cooling," Numerical Heat Transfer, Part A: Applications, vol. 71, no. 6, pp. 626-637, Mar. 2017.

[19] S. Panchal, R. Khasow, I. Dincer, M. Agelin-Chaab, R. Fraser, and M. Fowler, "Thermal design and simulation of mini-channel cold plate for water cooled large sized prismatic lithium-ion battery," Applied Thermal Engineering, vol. 122, pp. 80-90, Jul. 2017.

[20] J. Xu, C. Lan, Y. Qiao, and Y. Ma, "Prevent thermal runaway of lithium-ion batteries with minichannel cooling," Applied Thermal Engineering, vol. 110, pp. 883-890, Jan. 2017.

[21] A. H. Mohammed et al., "Design and Comparison of Cooling Plates for a Prismatic Lithium-ion Battery for Electrified Vehicles," presented at the WCX World Congress Experience, 2018, pp. 2018-01-1188.

[22] B. Ye, M. Rubel, and H. Li, "Design and Optimization of Cooling Plate for Battery Module of an Electric Vehicle," Applied Sciences, vol. 9, no. 4, p. 754, Feb. 2019.

[23] A. Pesaran, A. Vlahinos, and S. Burch, "Thermal Performance of EV and HEV Battery Modules and Packs,"p. 13.

[24] A. A. Pesaran, S. Burch, and M. Keyser, "An Approach for Designing Thermal Management Systems for Electric and Hybrid Vehicle Battery Packs," p. 18.

[25] M. V. Karvinkoppa and T. K. Hotta, "Numerical investigation of natural and mixed convection heat transfer on optimal distribution of discrete heat sources mounted on a substrate," IOP Conference Series: Materials Science and Engineering, vol. 263, p. 062066, Nov. 2017.

[26] V. K. Mathew \& Tapano Kumar Hotta (2020) Experiment and numerical investigation on optimal distribution of discrete ICs for different orientation of substrate board, International Journal of Ambient Energy, DOI: 10.1080/01430750.2020.1712255

[27] V. K. Mathew and T. K. Hotta, "Numerical investigation on optimal arrangement of IC chips mounted on a SMPS board cooled under mixed convection," Thermal Science and Engineering Progress, vol. 7, pp. 221-229, Sep. 2018.

[28] K. Mathew and N. Patil, "Convective Heat Transfer on the Optimum Spacing of High Heat Dissipating Heat Sources-A Numerical Approach," in Emerging Trends in Mechanical Engineering, L. Vijayaraghavan, K. H. Reddy, and S. M. Jameel Basha, Eds. Singapore: Springer Singapore, 2020, pp. 73-84.

[29] N. G. Patil and T. K. Hotta, "Role of working fluids on the cooling of discrete heated modules: a numerical approach," Sādhanā, vol. 43, no. 11, Nov. 2018.

[30] N. G. Patil and T. K. Hotta, "A Review On Cooling Of Discrete Heated Modules Using Liquid Jet Impingement," Frontiers in Heat and Mass Transfer, vol. 11, Jul. 2018.

[31 ] M. V K and T. K. Hotta, "Role of PCM based minichannels for the cooling of multiple protruding IC chips on the SMPS board - A numerical study," Journal of Energy Storage, vol. 26, p. 100917, Dec. 2019, doi: 10.1016/j.est.2019.100917.

[32] Mathew V Karvinkoppa and T.K.Hotta, "Transient analysis of Phase Change Material for cooling of discrete modules under mixed convection,', Journal of Energy and Environmental Sustainability, vol.8 oct 2019

[33] J. Li and Z. Zhu, "Battery Thermal Management Systems of Electric Vehicles," p. 79.

[34] School of Chemistry and Chemical Engineering, Henan Normal University, Xinxiang, Henan Province, 453007, China and S. Yang, "A Review of Lithium-Ion Battery Thermal Management System Strategies and the Evaluate Criteria," Int. J. Electrochem. Sci., pp. 60776107, Jul. 2019. 